\title{
ESPAÇOS E AGENTES DA OBRA
}

\section{Luis Alberto Brandão CNPq | FAPEMIG}

\section{Resumo}

A partir de questões sobre a noção de obra e seus corolários de unidade e concretude - questões que abarcam os vínculos entre obra e objeto, suporte, condições de apresentação, espaço perceptivo, mecanismos culturais -, proponho uma reflexão sobre as ambivalências de tal noção, bem como sobre as delimitações e os cruzamentos entre alguns dos principais agentes e dos respectivos processos de atuação a que a noção de obra se associa, como autor, editor, tradutor, leitor e curador. A reflexão toma como principal objeto as variantes de alguns textos de Zulmira Ribeiro Tavares publicados em diferentes ocasiões: na revista Cult, em 2000; no livro Vesuvio, publicado no Brasil em 2011; e na edição canadense, intitulada Vesuvius, publicada em 2015, com a tradução feita por Hugh Hazelton.

\section{Palavras-chave:}

Obra; Agentes; Espaços.

No presente ensaio, elegemos a noção de obra como ponto de partida para o debate sobre quais são seus espaços e quem são seus agentes, quais são os processos de espacialização e de atuação - sejam eles comumente observáveis ou desatendidos, pouco visíveis; formas historicamente consolidadas ou, ao contrário, emergentes ou apenas parte de um campo de possíveis. À noção de obra se vinculam dois corolários importantes, os quais desejamos desdobrar e problematizar: o corolário de concretude e o de unidade; ou seja, os corolários que indicam que, quando se fala em obra, pressupõe-se que ela possui um fundamento concreto, material; e que ela possui uma circunscrição identificável, limites que possibilitam que ela seja reconhecida como uma obra.

Tendo em vista que nos interessa colocar em discussão o que se entende por concretude, apresentaremos um exemplo em princípio bastante concreto e trivial; e tentaremos demonstrar, passo a passo, as muitas

\section{Abstract}

From questions about the notion of work (œuvre) and its corollaries of unity and concreteness issues that encompass the links between work and object, support, presentation conditions, perceptual space, cultural mechanisms - I propose a reflection on the ambivalences of this notion, as well as on the delimitations and crossroads between some of the main agents and their respective processes to which the notion of work associates, as author, editor, translator, reader and curator. The main object of the reflection is the variants of some texts by Zulmira Ribeiro Tavares published on different occasions: in Cult magazine, in 2000; in the book Vesuvio, published in Brazil in 2011; and the Canadian edition, entitled Vesuvius, published in 2015, with the translation by Hugh Hazelton.

Keywords:

Work (OEuvre); Agents; Spaces.

incertezas presentes em tal entendimento, em tal princípio e em tal sensação de trivialidade.

Nosso exemplo são três textos publicados na edição de dezembro de 2000 da revista Cult. São, obviamente, três obras concretas, cujas autonomias são certificadas pelos respectivos títulos (além do ano em que foram compostas). Os três textos são associados ao nome de sua autora, Zulmira Ribeiro Tavares, e esse nome já configura, pois, outro nível de unidade, à qual a autonomia das obras se subordina. Na página, que tem como título geral "Três inéditos", constam ainda uma foto e um minicurrículo da autora (os quais ocupam cerca de $1 / 3$ do espaço da página) e, no rodapé, a designação da seção: "Poesia Cult".

\section{OBRA: NÍVEIS - OU NATUREZAS - DE UNIDADE}

Vamos nos abster, aqui, de qualquer receio de especular a partir do que é trivial, ou aparentemente trivial, já que, em nossa opinião, 


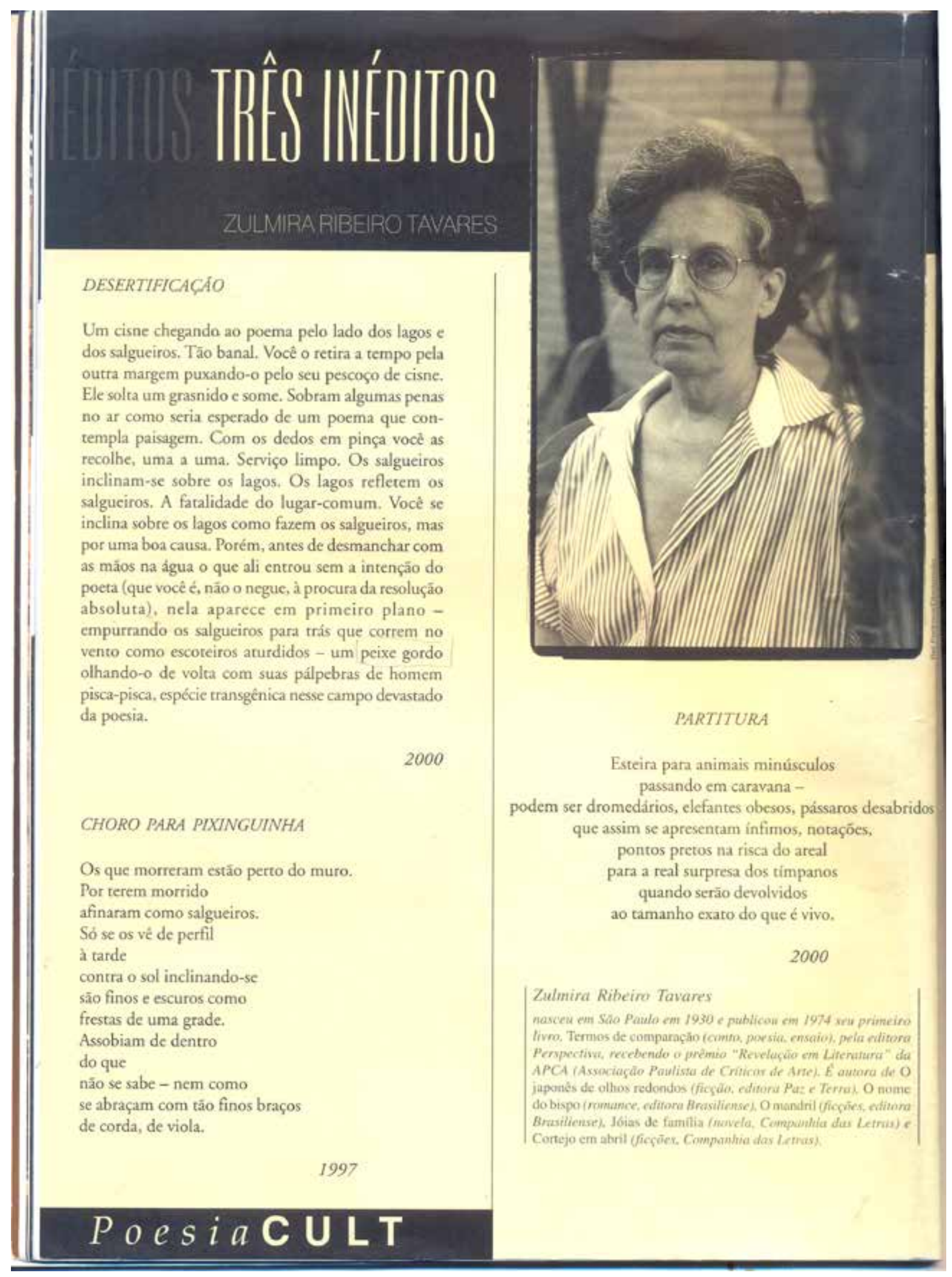

Figura 1 - três textos de Zulmira Ribeiro publicados na edição de dezembro de 2000 da revista Cult. Fonte: Arquivo Pessoal. 
trivialidade diz respeito justamente a um jogo de aparências naturalizadas, ou de evidências que se passam por autoevidências, isto é, que elidem os parâmetros que geram o efeito de evidência, à medida que são tomados como parâmetros indiscutíveis, ou, pelo menos, que não merecem ser levados em consideração. Assim, no exercício de rastreamento da trivialidade ou da suposta trivialidade (exercício que talvez venha a ser também a suspensão de seus efeitos), chamamos a atenção para o fato de haver diferentes níveis (ou, talvez, naturezas) de unidade projetados sobre a noção de obra.

Há, sem dúvida, a unidade de cada texto, cuja concretude se exibe espacialmente (são três blocos claramente identificáveis como independentes) e há uma unidade maior, que os agrupa a todos, vinculado ao nome da autora. Tal unidade, porém, além de ser de outro nível, mais abrangente (pois exerce uma função subordinadora), parece ser também de outra natureza: trata-se de uma unidade prioritariamente e literalmente nominal, já que sua função é vincular os textos a um nome de autor.

Se fosse apenas um nome, poderíamos mesmo sugerir, por um raciocínio simples, que se trata de uma unidade quase sem poder de concretização, ou seja, quase uma unidade abstrata: é possível que a obras - as quais, se entendidas como textos reconhecíveis como tal, são entidades concretas $\Psi$ se associem nomes - entidades em princípio abstratas (exceto, é claro, se houver elementos que o concretizem).

No exemplo, esse nominalismo, contudo, não é puro, pois vem acompanhado de uma fotografia, elemento altamente concreto tanto em si mesmo (a concretude da visualidade personificadora, pois se trata de uma foto que retrata alguém), quanto como efeito de concretização (o vínculo da imagem ao nome, os quais em princípio se tornam indissociáveis ou, idealmente, correspondentes). Deve-se observar, porém, que a foto está vinculada a um segundo nome, que aparece na margem inferior direita da foto - pela convenção atual, o nome da fotógrafa que a produziu, Bel Pedrosa - , ou seja, a outra instância com valores de propriedade e direito autorais.

Há, ainda, outro elemento importante, o minicurrículo, mas seu efeito de concretização é ambíguo. No minicurrículo, há basicamente três

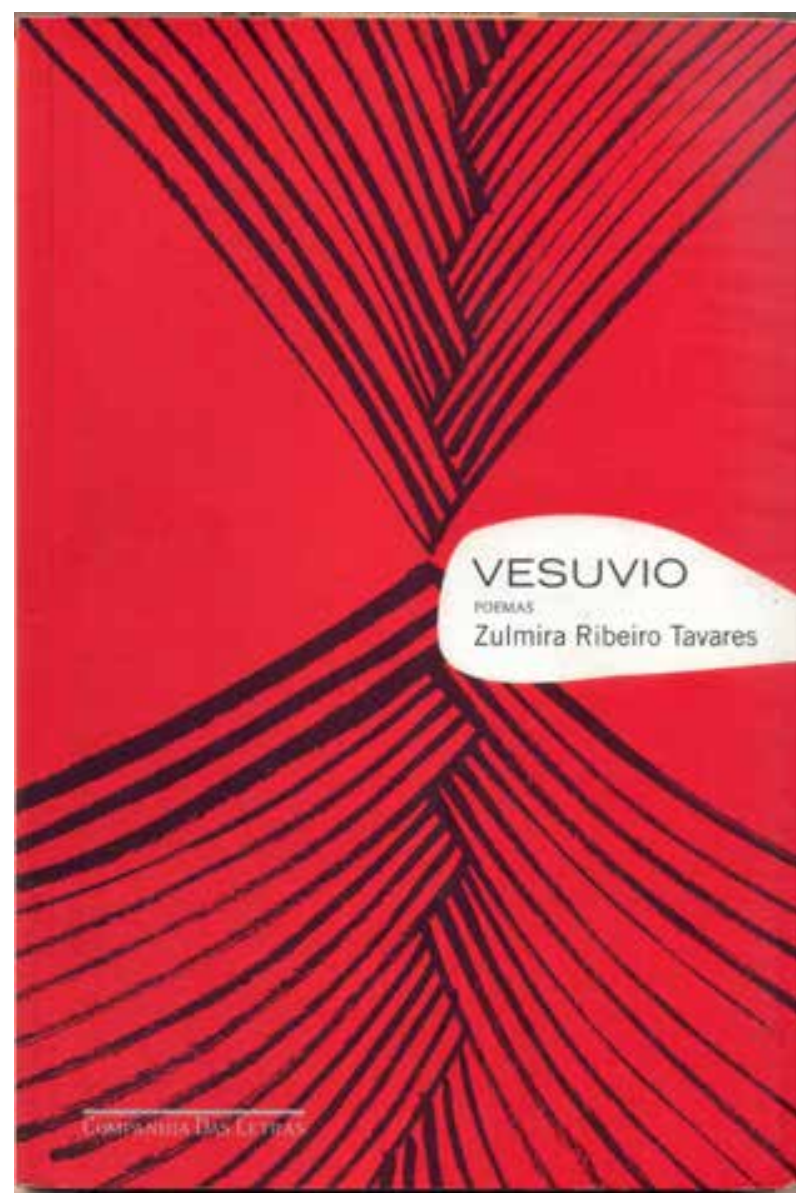

Figura 2 - capa do livro Vesuvio, de Zulmira Ribeiro. Fonte: Ed. Compania das Letras.

espécies de dados: local de nascimento; data de nascimento; títulos de livros, acompanhados de informações de editoras, gênero literário e premiações. Os dois primeiros - local e data de nascimento - reforçam o efeito concretizador da foto em relação ao nome, pois a ambos, foto e nome, tomados como equivalentes, agregam coordenadas espaço-temporais. É bom enfatizar que a existência de uma singularidade de localização e de datação costuma ser um pressuposto indispensável para a própria noção de concretude; no caso, de reforço do caráter empírico do sujeito ao qual se vincula o nome.

A última espécie de dados reforça o nominalismo - e, em certa medida, a abstração -, pois alinha nomes de obras (em sentido mais abrangente, pois nelas se agrupam textos longos ou conjuntos de textos). A noção de obra ganha, assim, uma nova dobra, pois indica uma unidade convencional ampla - a unidade do livro - e a existência de uma obra ainda mais geral, constituída pelo conjunto das obras autônomas; ou seja, a obra como a unidade composta por uma série de unidades; uma metaunidade; ou uma metaobra. 

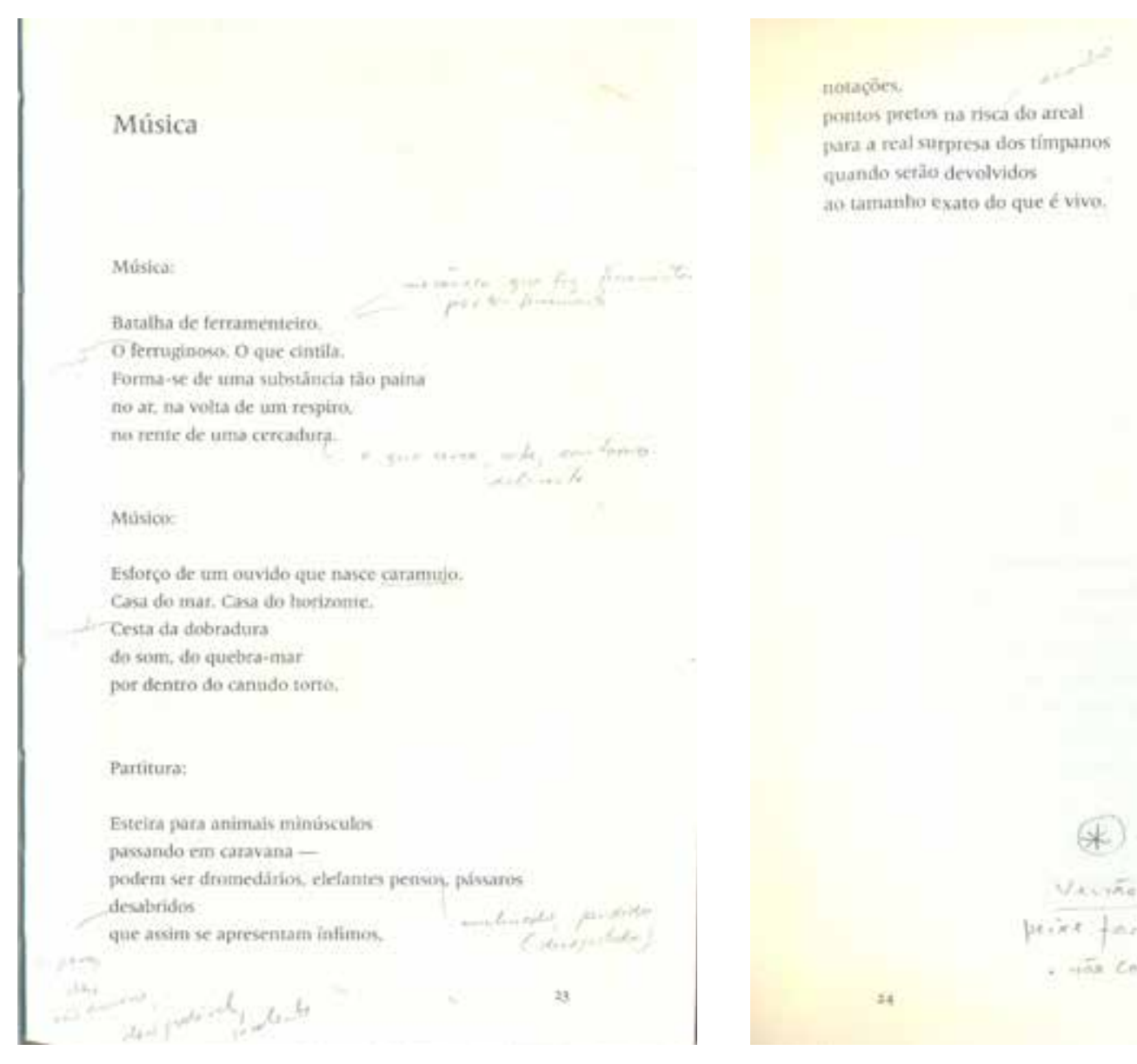

Figura 3 - páginas referentes ao poema "Música", de Zulmira Ribeiro. Fonte: Ed. Companhia das Letras.

Temos, pois, uma sequência de unidades em diferentes níveis, sendo que uma mudança de nível pode indicar uma mudança de natureza da própria noção de unidade. Há a unidade do texto (o texto como obra); há a unidade do livro (no qual as obras-textos se reúnem); há a unidade do conjunto das obras; e há, finalmente, a unidade da autoria (que parece se confundir, em parte, com o conjunto da obra; mas tal confusão não é plena, nem pacífica). Tal sequência parece ir de um nível mais concreto (cada texto) ao mais abstrato (o nome do autor como designação do conjunto da obra), lembrando-se que a foto e os dados espaço-temporais desempenham o papel de tornar menos abstrata a nomeação.

Há ainda um último elemento unificador, que reforça a noção de obra (embora não se confunda com ela): a referência a gênero literário. Como os três textos estão dispostos sob a rubrica "poesia", estão sendo caracterizados, de maneira supostamente inequívoca, como poemas. Ser um poema é também um índice de unidade, pois entende-se que um poema é uma obra, ou, dizendo-se de forma ainda mais explicitamente tautológica, reconhecer um texto como um poema é identificar a sua unidade como obra poética. Aqui mencionamos um aspecto nada desprezível, que diz respeito às convenções gráficas (convenções concretas, fundamentais para a percepção de cada texto em sua unidade de poema): em dois textos há uso de versos, ou seja, do elemento de descontinuidade dos subgrupos de palavras; porém, em um dos textos, intitulado "Desertificação", a apresentação é contínua, o que perturba a convenção mais difundida que vincula poema a verso, e prosa a texto contínuo. No caso do texto que não se estrutura em versos, o fator de unidade que identifica a obra como poética não se encontra na concretude da apresentação gráfica, visual, espacial, mas precisa ser buscado de outro modo (modo que exige que o texto seja necessariamente lido, e não apenas observado visualmente). 


\section{Desertificaçăo}

Um ctsne chegando as porma nelo Lado dos tagos e don salgueiros. T3̉o banal vocè o retira a sempo pela outra margem puxando-o pelo seu pescogo de cisne. Ele svila um grasnido e some. Sobram afgumas penas no ar como seria esperado de poenua que contempla galisagem. Com os dedos em pìnça vooé as recolhe, uma a uma. Serviço limpo. Os salgueiros inclinam-se sobte as lagios. Os lagos refletem os salyueires. A fatalidade do lugar-comum, Vocé se inclina sobre os lagos compo taxem os salqueires. mas por uma boa causa. Purém, antes de desmanchat com as thios na doua o que ali entrot sem a iniençỏo do pocta fque voot ć năo o negue, à procura

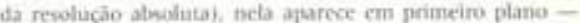
empurrando as salgueitos para unis que correm no vento como escoteiros aturdidos - um peixe tarto ollando-o de volta com suas pálpebras de horacum pisca-pisca, vocé, vocé, espécie tranygetuica nesse campo devastado da poesia.
Figura 4 - página referente ao poema "Desertificação", de Zulmira Ribeiro. Fonte: Ed. Compania das Letras.

\section{OBRA: DIFERENÇAS E REPETIÇÕES}

Introduziremos agora um novo desdobramento. As três obras-textos apresentadas na revista foram reapresentadas no livro Vesuvio, publicado por Zulmira Ribeiro Tavares cerca de dez anos depois, em 2011. Em nosso rastreamento da suposta trivialidade das constatações, precisamos destacar que o termo "reapresentação" é menos simplório do que pode parecer. Menos simplório porque não explicita uma série de relações de repetição e diferença. Em princípio, trata-se das mesmas obras-textos. Porém, há alterações tanto nas próprias obras-textos, quanto no que poderíamos chamar de "novo contexto de apresentação", o qual abarca muitas variações, entre as quais as mais nítidas são a nova vizinhança das obras-textos - o conjunto de obras-textos - e o novo suporte, o livro - o qual, é claro, não é apenas um suporte físico, mas também um conjunto de protocolos de validação, de autorização e de leitura (e aqui seria preciso convocar e problematizar todo um debate, imenso

\section{Choro}

para pixinguinba

Os q̨ue motreram estào perto do muro.

Por tetem morrido afinaram como solguciton

a contraluz

visiveis apenas de perfil

a rarde.

contra o sel indinando-se

șio finos e escutes

como frestas de uma grade

Asscbiam de dentro

do que

pho se sibe - nem some

te abraçam coen tho finos braços

Ae corda de viola.
Figura 5 - página referente ao poema "Choro", de Zulmira Ribeiro. Fonte: Ed. Compania das Letras.

e rico em variáveis, sobre em que medida o significado simbólico e cultural do livro afeta o que se entende por obra).

Já a expressão "publicado por Zulmira Ribeiro Tavares" também merece destaque, por se tratar de uma fórmula aproximada, pouco precisa, já que o "tornar público" envolve um conjunto enorme de agentes, os quais, por uma questão de economia, podemos agrupar sob a designação "agentes do meio editorial" ou, ainda mais simplesmente, o "editor". Nesse livro específico, à página 91 , há uma nota que menciona o fato de que alguns textos-obras haviam sido publicados anteriormente. Curiosamente, no entanto, não há qualquer referência ao fato de neles terem ocorrido alterações, como se se tratasse indubitavelmente dos mesmos textos-obra (ou seja, o fator repetição sobrepuja integralmente o fator diferença).

Não é nosso objetivo, aqui, fazer uma análise dessas variações. Comentaremos apenas brevemente alguns detalhes. No livro Vesuvio, 
"Partitura" não possui autonomia como poema, e sim faz parte de um poema maior, intitulado "Música". A distribuição dos versos e a diagramação são bastante diferentes. "Choro para Pixinguinha" ganha novo título: "Choro", seguido de uma dedicatória "para Pixinguinha". "Desertificação" recebe duas alterações de texto, pequenas, mas ambas significativas: a expressão "peixe gordo" é substituída por "peixe farto"; e um vocativo fortemente reiterado ("você, você") é adicionado na parte final do texto.

\section{OBRA: TENSIONAMENTOS DA UNIDADE}

Uma pergunta que nos parece inescapável é justamente quanto ao grau de relevância das variações, pois essa pergunta, no limite, tangencia outra: no caso em que as variações são muito importantes, trata-se ainda da mesma obra-texto? Será que é satisfatória a resposta de que se trata de um mesmo texto com diferentes versões? Se sim, satisfatória para quem? É claro que se pode supor ou postular que a unidade da obra-texto se preserva, independentemente das variações. É possível invocar princípios unificadores mais abrangentes, os quais teriam a capacidade de articular as variações. Há o princípio de autoridade do autor, entidade formal que sobrepujaria a concretude das obrastextos. Há, também, o princípio da autoridade e de auratização do livro, que sobrepujaria os outros suportes e formas de publicação. Há, ainda, o princípio do aprimoramento textual, que tomaria a relação entre versões anteriores e posteriores não apenas como relação temporal, mas de prevalência, ou seja, versões posteriores seriam sempre consideradas mais importantes e "definitivas", tendo em vista o pressuposto de que necessariamente são mais bem acabadas.

Nada impede, porém, que tais princípios não sejam acatados, e estamos pensando não apenas em leitores individuais, mas em sistemas de leitura amplamente difundidos, sobretudo em contextos culturais - como o atual - em que o acesso às muitas variações de uma obra-texto se torna viável. A partir da suspensão de tais princípios, não seria possível pensar que as variações, quando consideradas simultaneamente, comparativamente, configuram outra obra, outro tipo de unidade? Nos casos em que o tensionamento da noção de unidade pode vir a se mostrar relevante, não é a própria noção de obra que está sendo colocada em jogo?

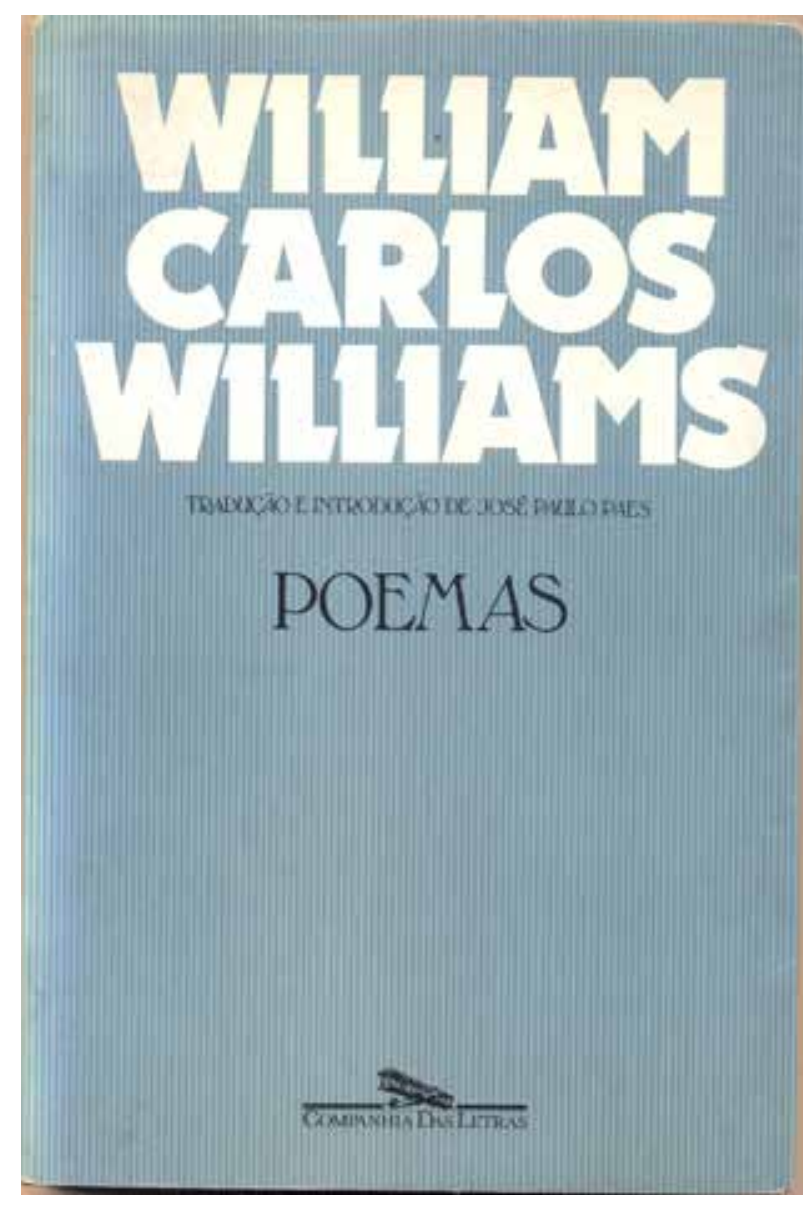

Figura 6 - capa do livro Poemas, de William Carlos Williams. Fonte: Ed. Compania das Letras.

Esse tensionamento pode já estar previsto na obra, como acontece quando sua apresentação, digamos, "oficial" possui mais de uma versão. Como exemplo, citamos o poema "The locust tree in flower", de William Carlos Willians, que tem duas versões, publicadas em sequência no mesmo livro. Ambas foram traduzidas para o português por José Paulo Paes. Ambivalentemente, as versões são ao mesmo tempo muito parecidas e muito diferentes. Devem, pois, ser tratadas como poemas autônomos? Como parte de um mesmo poema? Como um poema em série? Ou como o tensionamento da própria unidade do poema?

Questões como essas são muito importantes quando se introduzem na equação dos agentes da obra a figura do tradutor e a ação tradutória, pois ambivalência semelhante, no que diz respeito à unidade da obra, sempre ocorre quando se emparelham um suposto mesmo texto apresentado em línguas diferentes. Vale retomar a ideia de que o princípio de prevalência da anterioridade de um texto em relação a outro, princípio acima 


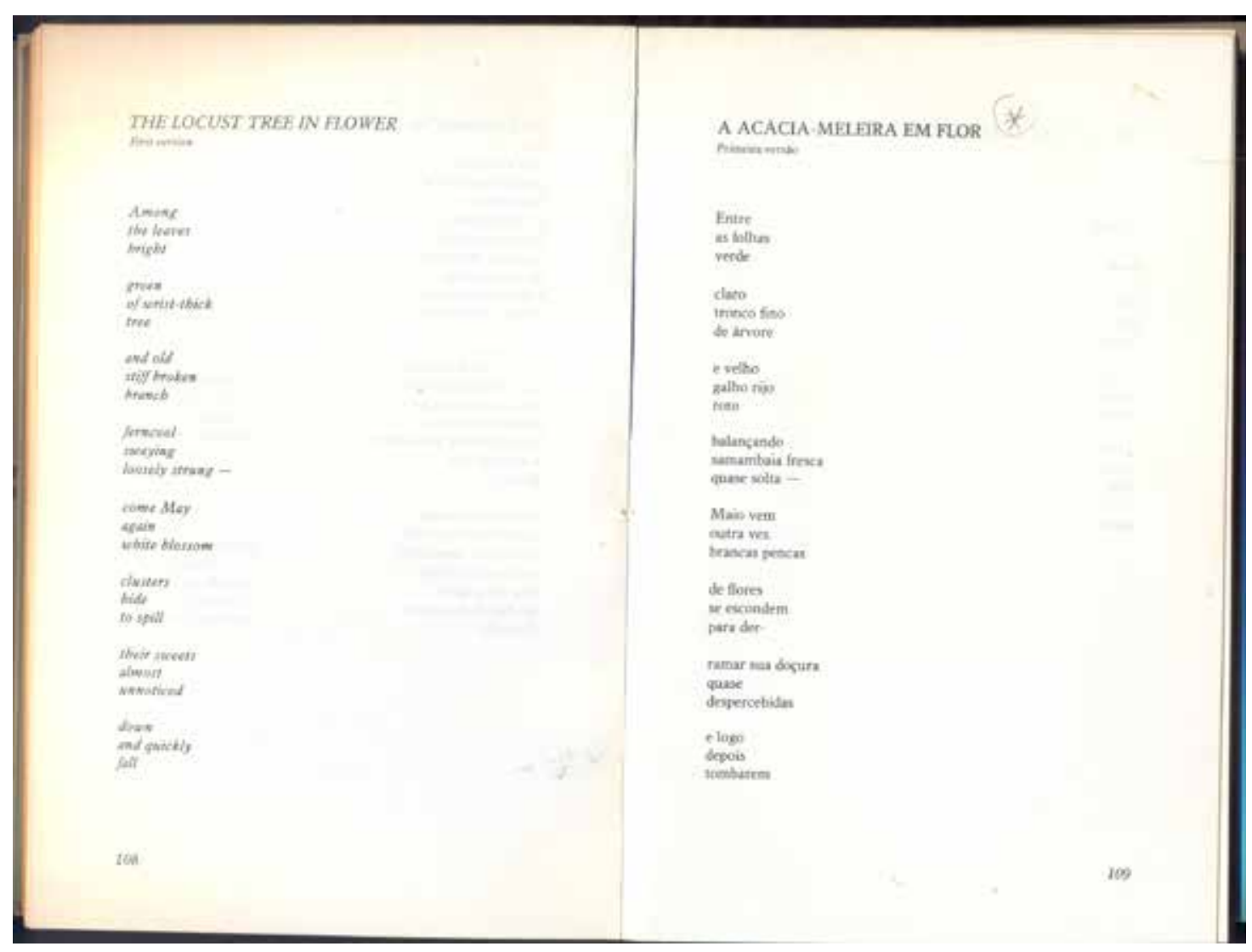

Figura 7 - páginas referentes a primeira versão do poema "A Acácia-meleira em flor", de William Carlos Williams. Fonte: Ed. Companhia das Letras.

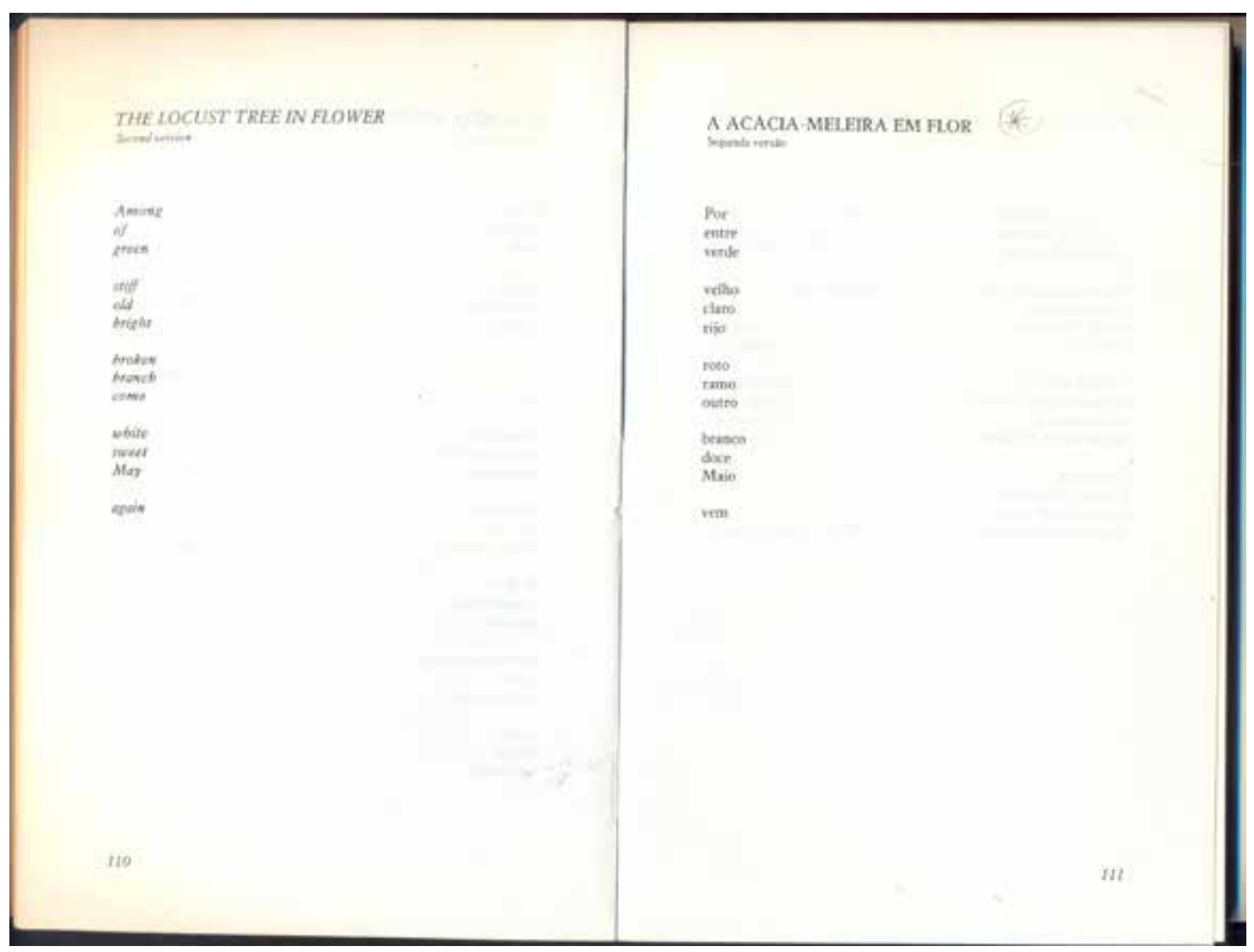

Figura 8 - páginas referentes a segunda versão do poema "A Acácia-meleira em flor", de William Carlos Williams. Fonte: Ed. Companhia das Letras. 
citado quanto a versões preliminares e versões supostamente definitivas (como é o caso das versões em revista e as em livro), também se manifesta na lógica que pressupõe que o texto na língua dita original é anterior ao texto na língua traduzida, anterior não apenas em termos de uma relação de temporalidade de produção, mas também de importância, de prevalência. Essa lógica já é observável na forte carga valorativa que se costuma atribuir à expressão "língua original". Igualmente vale retomar o comentário de que nada impede que tal lógica seja contestada, ou, pelo menos, colocada em suspenso, sobretudo em contextos em que existe o acesso a muitas versões de um suposto mesmo texto em diversas línguas, e, quando em uma mesma língua, segundo distintos parâmetros tradutórios.

\section{OBRA: AMBIVALÊNCIAS}

Toda edição bilíngue ou multilíngue explicita a referida ambivalência quanto à unidade da obra. Isso ocorre de forma ainda mais nítida quando os textos nas diferentes línguas são dispostos lado a lado, reciprocamente tensionando-se no que tange à expectativa de repetição e à inevitabilidade da diferença. Comentaremos brevemente alguns aspectos da edição canadense do livro Vesuvio/ Vesuvius, traduzido por Hugh Hazelton, e publicada em 2015. O primeiro comentário é que foram ignoradas as versões anteriores dos poemas citados, bem como dos demais poemas publicados anteriormente em outros veículos. Pode parecer irrefutável o argumento de que a proposta era traduzir "integralmente" o livro do modo como ele é "no original" - e, neste, as variações sequer são mencionadas. Pensamos, contudo, se tratar de uma escolha tão arbitrária quanto qualquer outra (embora, é claro, não sem motivações e consequências específicas), pois elege um determinado nível de unidade da obra - o livro como prioritário, mas supondo que tal prioridade se justifica por si mesma, ou seja, sem justificá-la. Além disso, tal horizonte de "integralidade da obra" se resume ao fato de que todos os poemas do livro e a nota do editor foram traduzidos e apresentados na ordem e nas seções em que aparecem na edição brasileira. Em todos os demais aspectos, que incluem desde os paratextos até a diagramação, não parece ter havido nenhuma intenção tradutória, no sentido de manter um paralelismo - reconhecível em alguma medida - com o livro dito "original".

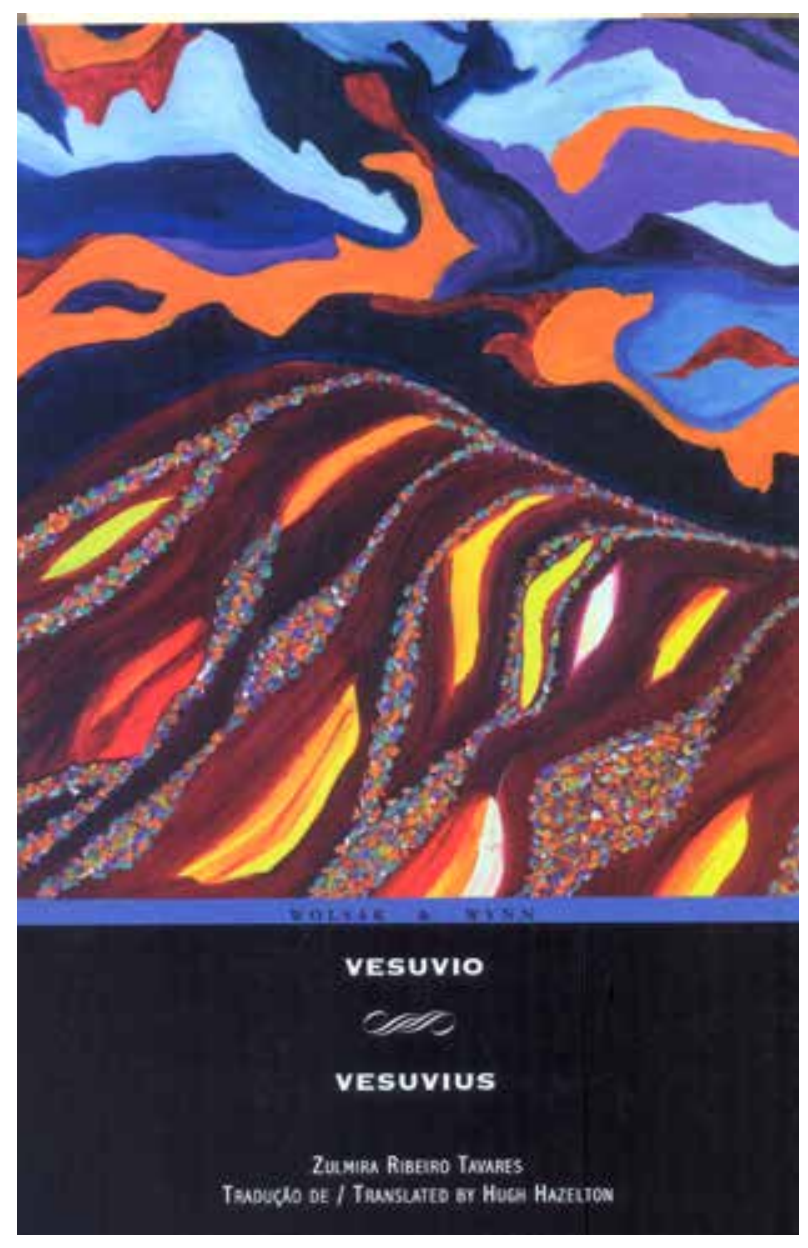

Figura 9 - capa do livro Vesuvio, de Zulmira Ribeiro. Fonte: Ed. Compania das Letras.

Mas tal ambivalência, perceptível na relação entre as duas edições - trata-se da mesma obra-livro ou são obras-livros distintas? -, é claramente percebida no fato de que a edição canadense explora de modo explícito a sua duplicidade. Tratase de um livro composto de dois livros, com dois títulos, com todos os paratextos apresentados em duas línguas. As únicas exceções são alguns dados da página de créditos. Mesmo sem adentrar no debate sobre o teor - duplo, é claro - dos poemas, comentaremos brevemente o efeito de suposto espelhamento-tensionamento dos poemas citados.

Nos poemas "Música" / "Music", no qual se incluem os poemas - ou partes de um poema - "Partitura" / "Score", chama atenção a diferença no espaçamento vertical, a qual rompe o efeito de espelhamento entre os poemas nas duas línguas. Como essa diferença não ocorre em outros poemas do livro, pode-se considerá-la mero erro de diagramação. Considerála assim, entretanto, não modifica certa sensação, a nosso ver nada desprezível, de assimetria visual. 


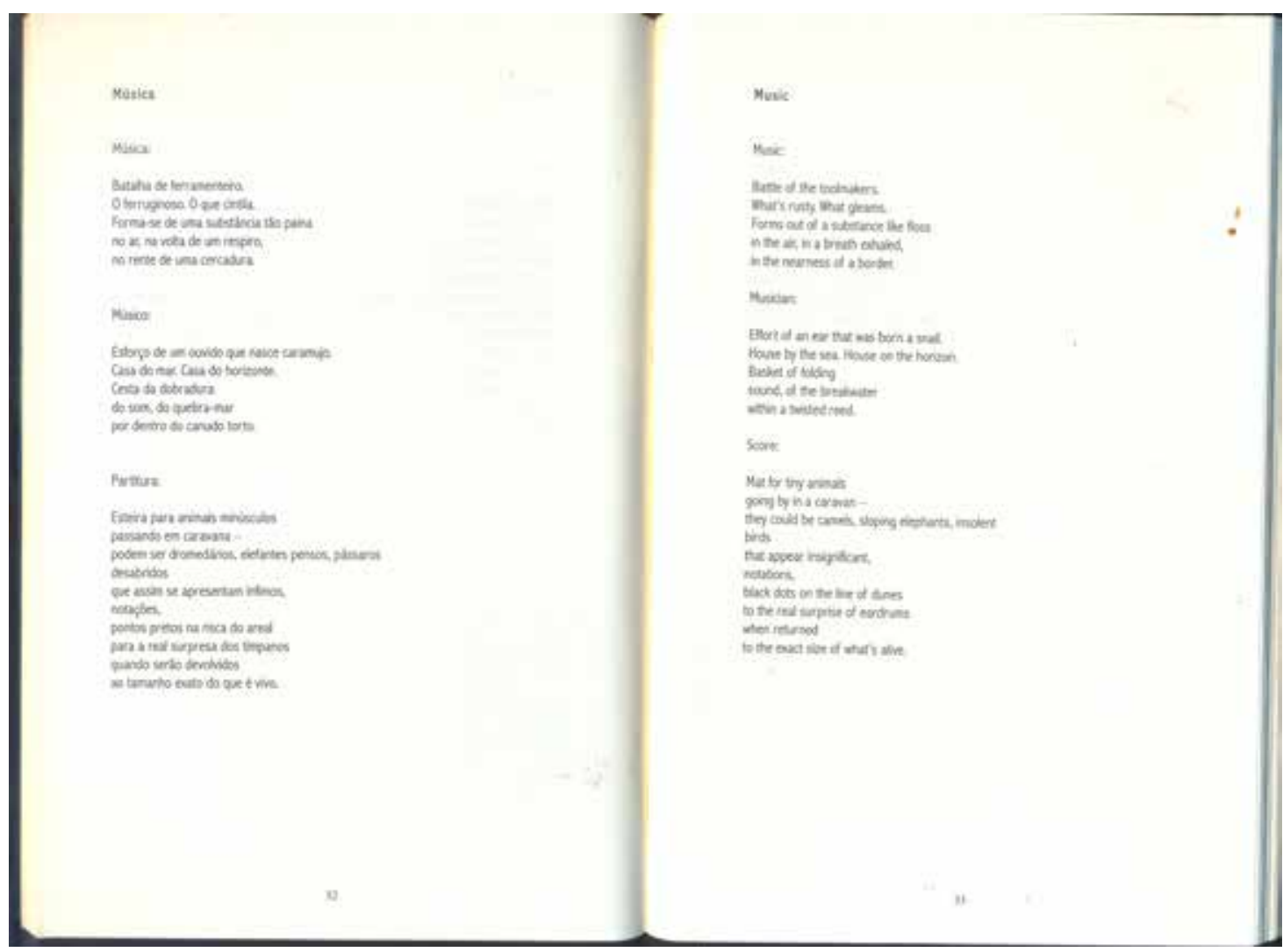

Figura 10 - páginas referentes aos poemas "Música" / "Music", de Zulmira Ribeiro. Fonte: Ed. Companhia das Letras.

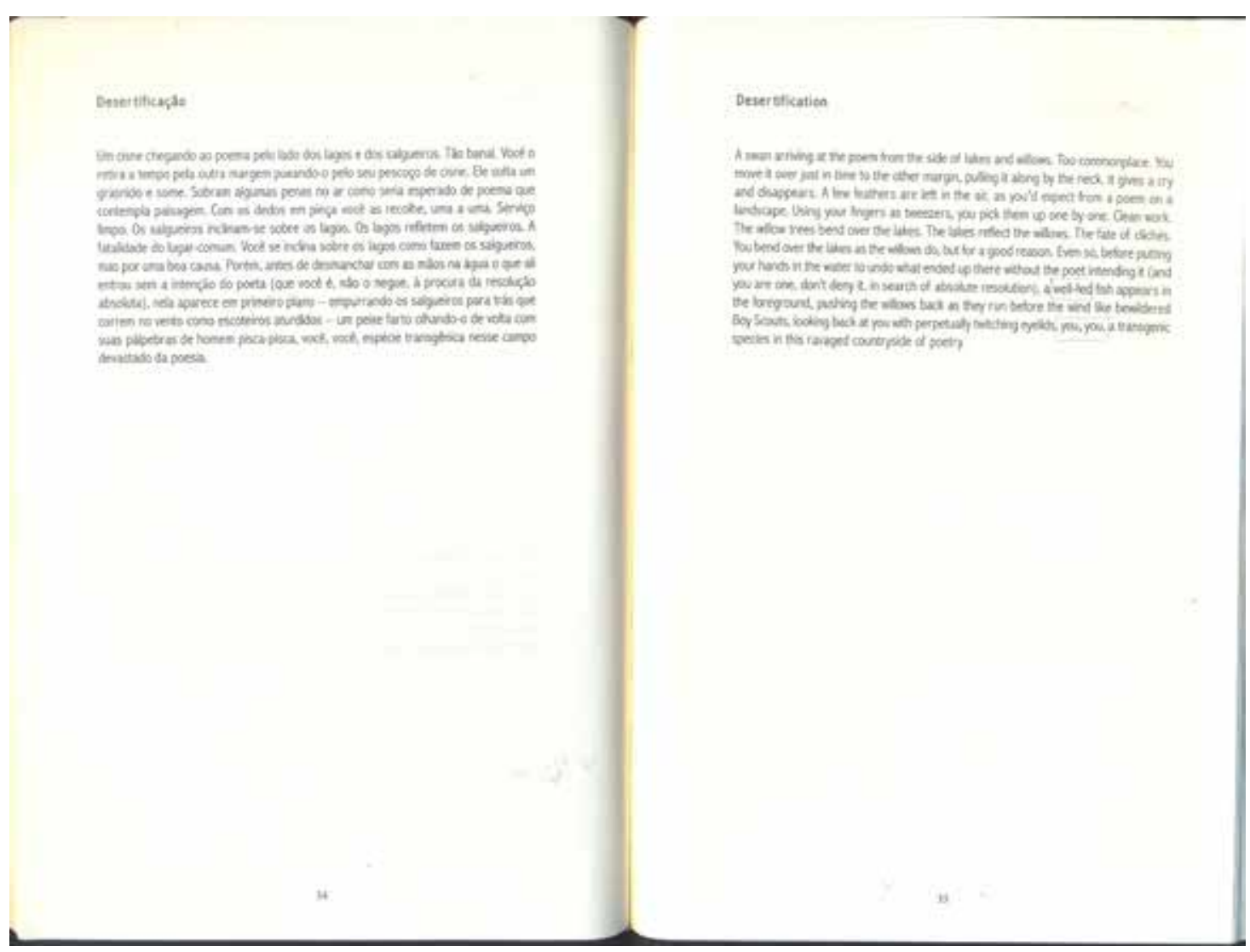

Figura 11 - páginas referentes aos poemas "Desertificação" / “Desertification", de Zulmira Ribeiro. Fonte: Ed. Companhia das Letras. 


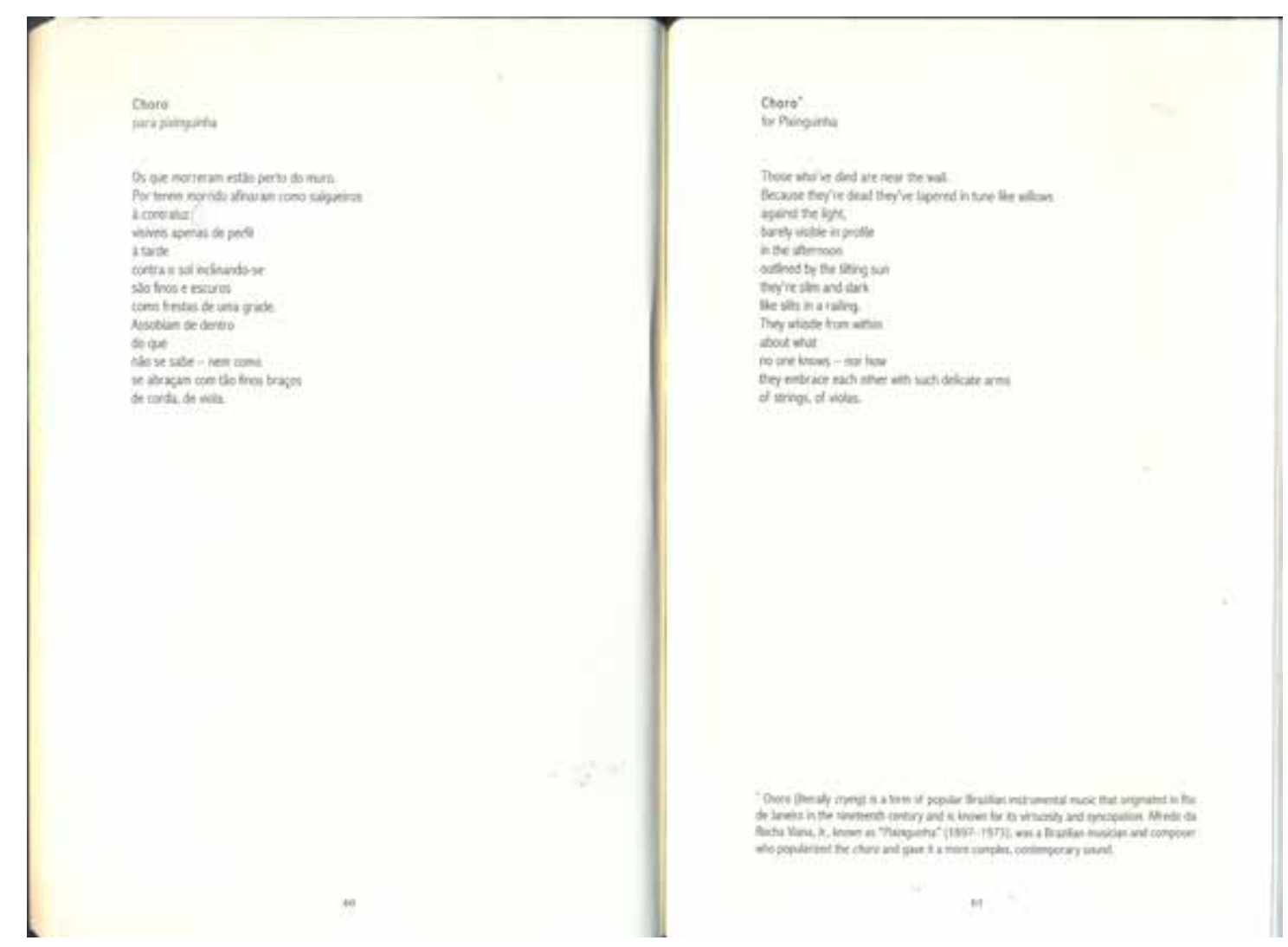

Figura 12 - páginas referentes aos poemas "Choro" / "Choro", de Zulmira Ribeiro. Fonte: Ed. Companhia das Letras.

Em "Desertificação"/"Desertification", os travessões no texto em português - os quais possuem função bastante singular, pois claramente destacam um bloco de texto com estranha sintaxe - são substituídos por vírgulas no texto em inglês, homogeneizando, pois, o uso dos sinais de pontuação. Mera questão de padronização editorial? Se levamos em conta que o uso dos travessões é mantido em outros textos traduzidos no mesmo livro, a resposta é negativa.

Sobre os poemas "Choro"/"Choro*", dois comentários. Primeiro: na edição canadense, a pontuação do poema em português não é igual à do poema na edição brasileira. Nesta, considerandose o padrão de uso de pontuação e maiúsculas no próprio poema e em todo o restante do livro, há sem dúvida um erro - o quarto verso deveria se iniciar com maiúscula. Tal erro fica ainda mais claro quando se consulta a versão do poema publicada na revista. A edição bilíngue, ao invés de corrigir o erro, introduz um novo, retirando o ponto final do terceiro verso. Segundo comentário: esse é o único poema cuja tradução ganha uma nota de rodapé, com informação sobre o choro como gênero musical e sobre o músico e compositor Pixinguinha. Nessa escolha se observa mais uma mudança de nível (de natureza?) na noção de unidade da obra, pois o texto se desdobra em texto e paratexto (ou, talvez, metatexto); a ação do tradutor se explicita como para-ação, o tradutor se assume como meta-autor.

\section{OBRA: SÉRIES DE QUESTÕES}

A partir do quadro esboçado, apontaremos sucintamente para seis séries de questões que nos parecem estimulantes como possíveis desdobramentos. Detalharemos apenas a primeira série, que diz respeito à possibilidade de identificar e propor tipos de unidade que categorizam a noção de obra. A primeira delas, provavelmente a mais comum, é a unidade que podemos chamar de estilística. Esse tipo de unidade, que pressupõe um horizonte autoral relativamente homogêneo e identificável, permite que se considerem como uma mesma obra, por exemplo, a primeira versão de um conto de Murilo Rubião, originalmente um datiloscrito de 1943 enviado a Mário de Andrade (e hoje disponível em livro) e a versão mais recente, com inúmeras alterações (inclusive e paradoxalmente, alterações estilísticas), publicada na Obra completa de 2012. 
Um segundo tipo se caracteriza não pelo critério unificador propiciado pela linguagem, mas, ao contrário, pelo fato de propor uma abertura à multiplicidade. Talvez o melhor exemplo seja o trabalho de Raymond Queneau e seus Exercices de style, em que cada texto é, como o título indica, a experimentação de um estilo diferente. A obra é ao mesmo tempo o que se apresenta e as muitas outras possibilidades, não realizadas, de apresentação. A obra é um algoritmo, ou uma equação, uma série articulada de regras ou variáveis que podem ser atualizadas de diferentes formas. Tal unidade, podemos chamá-la de unidade matricial.

Um terceiro tipo de unidade (ou de problematização da unidade da obra) pode ser didaticamente exemplificado com as relações entre o escritor Raymond Carver e o editor Gordon Lish. Com a publicação póstuma, em 2008, do livro Beginners, que traz as versões originais dos dezessete contos do livro What we talk about when we talk about love, lançado em 1981, tornou-se público o grau da intervenção operada pelo editor. Gordon Lish havia cortado entre quarenta e setenta por cento do teor dos contos. Naturalmente, não se trata de um problema relativo apenas à extensão dos textos, mas à própria configuração de um estilo, de um tom: o famoso "tom lacônico e seco" carveriano, inexistente - ou existente apenas em estado latente - nos textos ditos originais. Mas, nesse caso, qual é o texto original? Quem é o agente da obra prioritário: o editor ou o autor? A dificuldade - ou a impossibilidade - de responder tal pergunta sugere nomear tal unidade como unidade agonística.

Há ainda um quarto tipo, que abarca as obras de autoria múltipla. Toda obra coletiva representa, evidentemente, um problema para a noção de unidade e, por extensão, para a própria categoria de obra. Um bom exemplo é o livro Outras ruminações: 75 poetas e a poesia de Donizete Galvão, composto de 15 poemas do autor homenageado seguidos, cada um deles, de cinco poemas inéditos escritos a partir de sua leitura, cada um de um autor. Aqui, podese entender que a unidade é exógena, residiria no óbvio fato de os poemas estarem reunidos. Todavia, também é possível pensar que a conformação do conjunto viabiliza que os elementos sejam percebidos como unos. A unidade, nesse caso, é entendida não da perspectiva da intenção que gerou o agrupamento dos textos, mas da perspectiva do efeito gerado pela reunião. Há algo resultante da reunião dos elementos, algo que não se reduz ao que cada elemento gera isoladamente. Esse fator resultante é que seria a obra, pois é por meio dele que se manifesta o efeito de unidade. A esse tipo de unidade, ao mesmo tempo múltipla e articuladora, podemos chamar de unidade indecidivel.

Concluímos este ensaio enunciando as cinco outras séries de questões, desejando que possam ser desenvolvidas em novas oportunidades.

A primeira: pensar em termos de agentes da obra não implica apenas em uma mudança terminológica - em relação a pensar em termos de "a obra e seus sujeitos" -, mas uma mudança de lógica - focada em ações, processos, e não em entes, seres, sujeitos.

A segunda: quais são, como se estabelecem e como se modificam os modos e os parâmetros de institucionalização da própria noção de obra? E qual a especificidade da obra - literária, visual, cênica, musical, cinematográfica etc. - como instituição?

A terceira: quais são, em chave histórica, as relações entre os agentes da obra? Em especial, em que medida a figura do curador possui hoje uma potência que extrapola o campo das artes plásticas? Por que não pensar, por exemplo, a tradução como processo curatorial, em sentido expandido?

Quarta: de que maneira explorar os elementos caracterizadores dos gêneros textuais e/ou artísticos - como prosa e poesia - em seu papel de delimitadores da noção de obra? Tal exploração poderia se dar a partir, por exemplo, de valores contrastivos do tipo continuidade (prosa) e descontinuidade (poesia); retrospecção (prosa), prospecção (poesia)? Ou como a projeção de tais valores em distintas espécies de unidade, como: unidade estável (prosa), unidade instável (poesia); unidade convencional (prosa), questionamento dos limites da unidade (poesia)?

Quinta e última: o agente da obra mais difícil de caracterizar de forma precisa muito provavelmente continua a ser o leitor (ou o receptor). Como avançar em uma teoria da leitura e da recepção que escape à prioridade cognitivista ou semantizadora? Se o tradutor (ou o intérprete) é um híbrido de leitor e escritor (ou de receptor e autor), de que maneira a radicalidade dessa teoria outra da leitura e da recepção poderia afetar o entendimento da operação tradutória e interpretativa? 


\section{NOTAS}

01. Este ensaio vincula-se à pesquisa intitulada "EspaçosdaObra, FicçõesdoEspaço", desenvolvida com o apoio do CNPq - Conselho Nacional de Desenvolvimento Científico e Tecnológico - e da FAPEMIG - Fundação de Amparo à Pesquisa do Estado de Minas Gerais. Em sua versão preliminar, foi apresentado como conferência de abertura do VIII Fórum de Pesquisa em Artes da Universidade Federal do Pará, realizado em novembro de 2017 em Belém do Pará.

\section{REFERÊNCIAS}

ANDRADE, M. de; RUBIÃO, M. Mário e o pirotécnico aprendiz: cartas de Mário de Andrade e Murilo Rubião. São Paulo: IEB, Ed. Giordano; Belo Horizonte: Ed. UFMG, 1995.

CARVER, R. 68 contos de Raymond Carver. Trad. Rubens Figueiredo. São Paulo: Companhia das Letras, 2010.

CARVER, R. Beginners. London: Vintage Books, 2010.

CARVER, R. Iniciantes. Trad. Rubens Figueiredo. São Paulo: Companhia das Letras, 2009.

CARVER, R. What we talk about when we talk about love. New York: Vintage Books, 1989.

Cult - Revista Brasileira de Literatura. São Paulo, Lemos Editorial, ano IV, dezembro 2000.

DAMÁZIO, R.; PROENÇA, R.; MELO, T. de. (Org.). Outras ruminações: 75 poetas e a poesia de Donizete Galvão. São Paulo: Dobra Editorial, 2014.

QUENEAU, R. Exercices de style. Paris: Gallimard, 1947.

QUENEAU, R. Exercícios de estilo. Trad. Luiz Rezende. Rio de Janeiro: Imago, 1995.

RUBIÃO, M. Obra completa. São Paulo: Companhia das Letras, 2010.

TAVARES, Z. R. Vesuvio. São Paulo: Companhia das Letras, 2011.

TAVARES, Z. R. Vesuvius. Trad. Hugh Hazelton. Hamilton, Canada: Wolsak and Wynn, 2015.

WILliAMS, W. C. Poemas. Trad. José Paulo Paes. São Paulo: Companhia das Letras, 1987.

\section{SOBRE O AUTOR}

Luis Alberto Brandão é pesquisador do CNPq e da FAPEMIG, professor titular da Faculdade de Letras da UFMG. Ensaísta e ficcionista, publicou Teorias do Espaço Literário (Perspectiva, 2013, Finalista do Prêmio Jabuti, categoria teoria/ crítica literária), Manhã do Brasil (Scipione, 2010, Finalista dos Prêmios Portugal Telecom e São Paulo de Literatura), Chuva de Letras (Scipione, 2008, Prêmio Nacional de Literatura João-deBarro, Finalista do Prêmio Jabuti, selecionado para o Programa Nacional Biblioteca da Escola, do MEC), Grafias da Identidade (Lamparina, 2005, Finalista do Prêmio Jabuti, categoria teoria/ crítica literária), Tablados (7Letras, 2004), Um Olho de Vidro: A Narrativa de Sérgio Sant'Anna (Fale/UFMG, 2000, Prêmio Nacional de Literatura Cidade de Belo Horizonte, categoria ensaio) e Saber de Pedra: O Livro das Estátuas (Autêntica, 1999, Bolsa Vitae de Artes). Atualmente desenvolve o projeto "Espaços da Obra, Ficções do Espaço" e é líder do grupo de pesquisa Espaços Literários e Transdisciplinares, cadastrado no Diretório de Grupos do CNPq. 